\title{
SOCIAL HOUSING MANAGEMENT IN POLAND IN THE CONTEXT OF AGEING SOCIETY. EUROPEAN EXPERIENCE AND IMPLICATION FOR POLAND
}

\author{
Zuzanna Rataj ${ }^{1, a, *}$, Rafał Iwański ${ }^{2, b}$ and Beata Bugajska ${ }^{3, c}$ \\ ${ }^{1}$ Poznan University of Economics and Business, Faculty of Economics, Department of Sociology and \\ Business Ethics, Poland \\ ${ }^{2}$ University of Szczecin, Faculty of humanities, Department of Social Pedagogy, Poland \\ ${ }^{3}$ University of Szczecin, Faculty of humanities, Department of Social Pedagogy, Poland \\ azuzanna.rataj@ue.poznan.pl, brafaliwanski@wp.pl, cbbugajska@o2.pl \\ *Corresponding author
}

Cite as: Rataj, Z., Iwanski, R., Bugajska, B. (2017). Social housing management in Poland in the context of ageing society. European experience and implication for Poland, Ekonomicko-manazerske spektrum, 11(2), 22-31.

Available at: dx.doi.org/10.26552/ems.2017.2.22-31

\begin{abstract}
The process of population ageing has a global dimension and constitutes an important challenge for social policy, and in particular for housing policy. Demographic forecasts carried out by Eurostat, World Bank and the UN unanimously predict an increase in the number of the elderly, especially seniors aged $85+$. The ageing of Polish society and the implications of the process for the housing sector is a challenge for social policy, which is responsible for creating an enabling environment to meet the needs of older people. Increasing expenditures on care for the elderly points to the need to find appropriate solutions for independent or partially independent seniors living in their own housing environment. The large percentage of Poland's population aged 65 and older requires that housing policy seek solutions for the implementation of housing needs at a level appropriate to the needs of different groups. It is important to discuss the necessity to secure housing needs of the elderly, especially seniors with low level of independence. The development of senior housing, sheltered flats, residential homes and old people's homes could bring a solution to the increasing demographic problem. The discussion concerns the European context and the implications that can be derived for Poland. The dynamic increase in the number of older people in the society is a complicated and relatively new phenomenon in Poland, therefore in the contemporary economic and sociological discourse there is a growing interest in the ways of increasing supply of housing units that meet the needs of the elderly. In the paper the authors describe management of the social housing stock (Lennartz et al., 2012; Czischke, 2012) that addresses the issue of securing housing needs of seniors. The discussion concerns the European context and the implications that can be derived for Poland.
\end{abstract}

Keywords: social housing, senior housing, management of social housing stock

JEL Classification: A13, J11, J14, J26, Z18

\section{Introduction}

Improving living conditions of the population, technological progress and medical development have resulted in the growth of the number of the elderly in many societies. This phenomenon is becoming a global one, and statistical data allow for drawing a conclusion that 
it is going be valid for many years in the future. (Eurostat, 2016a) Population ageing is relevant also for the Polish society. The demographic forecasts predicting a progress of the said process induced the Polish government to seek innovative solutions allowing seniors to live independently at the advanced age. Importance is increasingly often attached to the ideas of ageing in place evolving in Western Europe that facilitate the maintenance of independence and self-reliance (Hillcoat-Nalletamby, 2010) by adapting dwellings to the needs of older people. This is corroborated by research on seniors ' preferences which show that they want to live in their familiar environment as long as possible. (Vanleerberghe et al., 2017; Gonyea \& Burnes, 2013) The idea differs in various European countries (Houben, 2001) depending on the current social policy. (Esping-Andersen, 2001) It is no different in the case of the housing policy, which is variously understood and pursued, also towards older people, depending on the housing system adopted by the particular country. (Kemeny, 1992)

In the beginning, ageing in place was limited to ageing in one's own living environment and neighbourhood, due to which seniors had a sense of stability and safety translating into a better quality of life. (Bowling et al., 2003) Currently, the idea has a much broader sense. The World Health Organization Centre for Health Development (WHO (2004)) defines it as follows: meeting the desire and ability of people, through the provision of appropriate services and assistance, to remain living relatively independently in the community in his or her current home or an appropriate level of housing. Aging in place is designed to prevent or delay more traumatic moves to a dependent facility, such as a nursing home. This definition underlines the significance of the place of living in the life of the senior. It seems to be of key importance to adapt the place of living of an older person to their needs, both primary and higher ones (Wei et al., 2015), including those arising out of the age, for that person to live independently as long as possible. This is why new housing solutions, including innovative ones, are promoted, such as assisted living housing, sheltered housing or dedicated housing where elderly people may receive support depending on their ability to live independently. (Suszynska \& Boruta, 2017) Due to the nature of social housing, defined by the European Commission as (European Commission, 2010) dwellings at affordable prices as well as their allocation within a specific system, the authors of this paper consider it one of the available tools that may provide for the meeting of needs of the elderly, including with the implementation of the idea of ageing in place. In Poland, the said idea is not very popular, and its demonstrations may be found only incidentally, and only owing to the involvement and initiative of particular local authorities or private entities. Some information used in the process of drafting this paper was obtained while conducting a research project "Social Housing and Its Role in Satisfying Housing Needs of Indigent Households in Poland" funded by the National Science Centre (2014/13/N/HS4/02100).

\section{Methodology}

The aim of this paper is to explore European solutions in the field of satisfying housing needs of older people, in particular with emphasis on the idea of ageing in place, by comparing measures applied in France, the UK and Sweden, and further to examine which of these solutions are fit to be implemented in Poland. These considerations result from the analysis of only few projects carried out in Poland in the field of satisfying housing needs of older people in Poland, in particular those including the idea of ageing in place.

The paper presents issues relating to social housing in the context of securing housing needs of the elderly in selected countries of the European Union (EU) (representing different social policy models (Malpass, 2008), with special emphasis on the needs of dependent people. In line 
with the idea of deinstitutionalization of long-term care for dependent older people, a necessity may be observed in many countries to develop housing and auxiliary infrastructure which would allow seniors for self-care, and in the case of people with low level of independence, for the provision of safe and proper care at the place of living.

The hypothesis formulated herein is that in face of the growing number of older people, social housing in Poland may play a vital role in satisfying housing needs of seniors; the condition for their efficient implementation, though, is to construct dwellings allowing for ageing in place. To verify the said hypothesis the authors carried out desk research of a variety of academic databases, such as Web of Science, Scopus, Wiley Open Library and Elsevier, as well as national and international documents providing for the right to housing and right to residence. The paper also uses statistical data from national and international institutions demonstrating the process of population ageing up to 2050 . The research was conducted in three stages.

Stage 1: Collecting statistical data allowing to determine demographic trends in Poland and Europe; furthermore, comparative analysis was carried out aimed at evaluating the situation in Poland as compared to other EU countries.

Stage 2: Collecting references concerning social housing and the idea of ageing in place; stage 2 was aimed at analysing solutions in the field of social housing in the context of ageing society, in particular with the implementation of the idea of ageing in place; furthermore, solutions applied in selected EU countries, i.e. Germany, the UK, France and Sweden, were analysed.

Stage 3: With reference to the research hypothesis formulated, stage 3 was the answer to the question whether social housing may constitute a tool to satisfy housing needs of the elderly in accordance with the idea of ageing in place; within stage 3, Polish solutions in the field of housing policy were analysed, including with consideration of the needs of older people in Poland, and the possibilities were examined to implement Western European solutions in Poland.

\section{Result}

\section{Demographics: Current State and Prediction}

The ageing of the populations in the EU countries is of global nature. The expected growth of the number of older people, provided the low fertility rate will be maintained, will lead to the growth of the share of the elderly in the population. This will create a challenge for the European social policy in several areas: the social, economic and health-related one. (Lunenfeld \& Stratton, 2013) The authorities of the countries where the population is ageing will have to solve acute social problems relating to the demographic process under discussion. The main categories of the challenge would include: increased burden imposed on pension schemes; a lower number of people at working age; increased demand for performances provided by healthcare entities; an increased number of people requiring aid and assistance in everyday life (Wisniowska-Szurlej et al., 2017); and increased income inequality. (Vandenbroucke, 2016) The economies of particular EU countries, including Poland, need to develop dynamically to adapt to the demographic changes and manage the challenges to come. (Hoagland (2016-17)) Population ageing is a unique process in historical terms. An urgent need is visible to undertake measures preventing the growth of social inequality in terms of access to medical and care services (Wim \& Van Den Heuvel, 2015) due to the inability to satisfy them to the full extent.

In the case of the EU15 countries the problem of population ageing has been present for years, whereas in the countries of Central and Eastern Europe (CEE) the process started 
somewhat later but is very intense. In 1990, the share of people aged 65 and more in the CEE countries fell approximately at $11 \%$. In the same period, Western Europe saw a share of the elderly in the population of more than $14 \%$. For the next two and a half decades the share of older people grew, and in 2016 fell at $17.4 \%$ in the CEE countries, and at $19.46 \%$ in the entire EU. (World Bank, 2017) In Poland, in 1990 people aged 65 and more constituted only 10\% of the population. In the case of France, in the comparable period that share amounted to $14 \%$, in the UK 15.8\%, and in Sweden to 17.8\%. Comparable to Poland was the scale of ageing of the population in France, where the share of seniors grew by more than 5 percentage points and fell at 19.3\%; similar values in 2016 were noted in Sweden (19.8\%) and the UK (18.4\%) (World Bank 2017). According to the demographic forecasts, in 2050 the populations of Sweden (22.7\%), the UK $(23.9 \%)$ and France $(25.6 \%)$ will have a lower share of older people than the expected average of the current EU $(28.5 \%)$, whereas in the case of Poland the share of the elderly in the mid-2 $1^{\text {st }}$ century will exceed 30\%. (Eurostat (2016a)) For two and a half decades, in all countries the number of seniors within the population grew as compared to people at working and pre-working age. Moreover, long-term migration of people at working age from peripheral territories (in regional and national terms) to cities contributes to the growth of the elderly share in the population. (Iwanski, 2013) This is valid in particular for rural areas, where the share of the elderly amounts to approximately $30 \%$. Such a situation may be observed in Greece, Spain, France and Portugal, as well as in the eastern part of Germany. (Eurostat, 2016a) In 2017, the median age of the EU population amounted approximately to 42.5, and according to the demographic forecasts it will grow to 46.6 in 2050 . In the mid- $21^{\text {st }}$ century, the highest median of age will be noted in Portugal (52.4), Greece (52.3), and Lithuania (51.8), and Poland will be one of the fastest ageing countries.

In 2017 , the median age in that country was approximately 40, and it will grow by more than 10 years and exceed 50 by 2050 . The mid- $21^{\text {st }}$ century will see the youngest populations in Ireland (41.7), Sweden (41.8), the UK (43.1) and France (42.7). In the case of Sweden, the demographic forecasts show the growth of the median in the next three decades only by less than a year, and 1.5 year in France, which is due to a relatively high fertility rate falling around the value providing for the demographic renewal and positive net migration rate. (Eurostat (2016b)) Of particular significance is the expected growth of the number of the citizens at the so-called advanced age, i.e. those who are over 80 years old. In 2016, people from that age group constituted $5.4 \%$ of the population of the EU countries, while in 2050 that share will increase to more than $11 \%$. The same period will see a decrease of the share of people at working age: from $65.3 \%$ in 2016 down to $56.7 \%$ in the mid- $21^{\text {st }}$ century. (Eurostat, 2017)

The presented data are particularly important in the context of the discussed issues relating to the trends in the development of the housing policy towards older people, due to the forecasts showing that the care service potential of the particular EU populations will diminish. This will result in a decrease of people at working age able to provide care services to senior citizens, and at the same time an increase of people at advanced age. The risk of dependence grows with age, and the need of care becomes permanent and long-term. (Iwanski, 2016) During the entire process of care over an old person, the involvement of care service providers grows. This is why it seems necessary to promote active ageing and maintenance of independence. For this to be possible, however, proper conditions, including housing ones, must be provided for. (Giada Meda, 2014)

\section{Social Housing. European Perspectives}

Ch. Donner (2000) points out that social housing may take multiple forms. In certain countries, these are fully subsidized facilities, in others both public housing and limited-profit housing is considered social. In addition, the author points out that sometimes social housing 
includes also the private sector, provided the rents are maintained below the market value with the aid of public intervention. Housing is provided by public entities, including municipalities, and private ones, i.e. developers, who, however, are not completely free to determine the level of rents. Donner (2000) and Kemeny (1995) based on how rents are set, draws a distinction within the housing construction between the profit rental sector and the non-profit rental sector. He considers entities setting rents at the level of dwelling replacement value to be acting not for profit, regardless of whether these are public or private entities. Entities aiming at maximizing the profit from the housing property, thus acting for profit, are usually represented by private organizations. Social rental housing in traditional terms may be defined as the resultant of the following factors (Priemus, 2007):

- housing was built with the use of State funding,

- housing was subsidized by the national government,

- principal and administrator were either the local council or a non-profit organization,

- rents were held below market levels,

- dwellings were intended for, and largely occupied by, low-income households.

The above definition, however, has become out of date in the recent years. Judging from the developments in social housing, it may be said that the first factor became outdated in many countries: other entities, including commercial ones, are involved in investing in the housing sector. Secondly, the contemporary interventionism in the housing sector is much narrower and more selective: the current social housing systems feature far-reaching decentralization, democratization and shifting the management and service provision processes into the free market. (Suszynska \& Strączkowski, 2013; Rataj \& Suszynska, 2017) Thirdly, European countries adopted various market-based allocation schemes which are gradually driving out the traditional administrative allocation, e.g. the CBL system in the UK (Manley \& Van Ham, 2011; Clapham \& Kintrea, 1984) and the so-called Delft model in the Netherlands. (Van Daalen \& Van Der Land, 2008)

\section{Social Housing in Poland}

According to the National Census (GUS 2013), in 2011 there was no deficit of dwellings in terms of quantity in Poland. There is, however, deficit of quality: many dwellings are not occupied due to their technical condition, and the number of substandard dwellings is steadily high (1.3 million dwellings according to the National Census 2011). To a considerable extent these dwellings belong to municipalities and are incorporated in the municipal and social stock, which means people experiencing financial or health difficulties are forced to use housing of lower quality. The problem becomes essential in the context of the growing number of seniors who in the near future will need dwellings adjusted to their needs due to insufficient capacity of nursing homes and the changing paradigm, i.e. deinstitutionalization. Thus, the demand for assisted living, sheltered and dedicated housing in Poland will grow. Due to the significance of the population ageing issue and the importance of home in the life of every person, the authors find that social housing, as a specific part of residential housing, may prove to have huge potential for the development of senior housing aimed at solving the increasing problems. Within it, the idea of ageing in place should be taken into account to provide for the proper quality of life for the elderly.

Senior housing is a response to the needs of ageing populations. It includes not only care services but also assisted living and independent living. (Schnure \& Venkatesh, 2015) In Poland senior housing is not sufficiently developed. Only in few cities investment in this area has been undertaken, and only one applies the idea of ageing in place. The main forms of senior housing in Poland are assisted living housing and dedicated housing. The first one is arranged by the local government, who is the key investor. Assisted living housing is intended for older people 
who are able to exist independently but may require support from community workers to a limited extent, e.g. one hour a day for shopping. Particular dwellings and entire buildings are adapted for the needs of people with disabilities and are barrier-free to facilitate independent living for seniors. The dwellings are approximately 40 to $50 \mathrm{sq}$. $\mathrm{m}$ large and are intended for one single person or two related people. In 2015, in Szczecin 23 assisted living dwellings were launched within social housing, and the entity responsible for supervision and recruitment is the local social care unit. Another form is dedicated housing. The only dwelling of the type in Poland was completed in 2016 in Warsaw. The one-bedroom flat is developed and fitted so as to meet the needs of seniors who expect to maintain independence with proper comfort. The cost of adapting and fitting the dwelling amounted to approximately EUR 42 thousand, and the price of the dwelling is to be added to the total investment cost. In the coming years, local governments may be expected to invest in the development of assisted living housing for institutionalized forms of care over dependents are being abandoned. Introduction of a nationwide programme will be considerably hindered as most local governments will not be able to bear the costs of this type of investment. The private sector will face new prospects due to the ageing of the post-war demographic high generation, strong and steady tendency of long-term outward migration of people at working age, which translates into decrease of care provision potential within families. A part of older people, in desire to remain within their own environment at the advanced age, will probably try to adapt their dwellings to the needs of older people or decide to purchase a dedicated dwelling. In the case of purchase, aid from the local government may be required due to the financial standing of older people. Thus, it seems to be reasonable to seek new solutions that may expand the availability of senior housing.

\section{Discussion}

\section{Senior Housing in European Union Countries and Implications for Poland}

The authors analysed senior housing in selected EU countries: Sweden, France and the UK. The criterion to select the countries were different social policy systems. Sweden, as one of the countries which faced population ageing quite early, is experienced in providing support for older citizens, including that in the area of housing. The most important forms of housing support addressed to seniors are: living at home, dwellings for independent senior living, assisted living residence, nursing homes and specialized care. (Lewicka, 2015) From the point of view of ageing in place, the following seem to be most vital: living at home, dwellings for independent senior living and assisted living residence. Support in form of living at home is based on the prerequisite that the elderly have the right to live independently in decent conditions as long as possible, and so municipalities provide support of home care staff. Older people who require assistance in everyday living may purchase services provided by municipalities themselves or by private entities hired by municipalities. Such services include, among other things, delivery of meals, assistance in shopping or cleaning the house. (Lewicka, 2015) Furthermore, if the property occupied by an older person is not adapted to special needs, they may obtain funds from the local government to adapt it properly. (Edstrom \& Gustafsson, 2015) Dwellings for independent senior living are not much different from usual dwellings. They are dedicated for people aged 55 or more, and the idea consists mainly in adapting the dwelling (bathroom, rooms) to the needs of people with various medical conditions, e.g. somatic ones. The main assumption of this type of dwellings is to extend the independence of seniors for as long as possible and to maintain relations between neighbours in the community. The last type of housing, assisted living residence, is addressed to people over 70. The beneficiaries receive also additional support from qualified community workers who, apart 


\section{Housing Needs of the Older People. European Experience and Implication for Poland Authors: Zuzanna Rataj et al.}

from everyday assistance, provide also medical and nursing assistance. This is a solution dedicated to seniors who do not require long-term care and only have difficulties with everyday tasks. (Fukushima et al., 2010)

Senior housing in Sweden is funded chiefly from municipal taxes and government grants, as well as, to an inconsiderable extent, by the older people themselves. The amount of funding depends on the particular municipality, but in each one seniors with health or financial difficulties may apply for decreasing the costs of living. (Klevmarken \& Lindgren, 2008) What is important, the expenditures for senior care constitute the most important expenditures of the municipalities, which are obliged to provide for care to the elderly and to fund it. Furthermore, municipalities seek such solutions to allow older people to remain living at home for as long as possible. Such a solution brings positive effects: first, the costs of living of older people are lower; no special nursing homes have to be sought for them; it allows them to remain in their community; and municipalities may privatize part of services and thus affect the prices thereof.

In the UK, emphasis is placed on promoting the idea of independence of the elderly. This is why dwellings adapted for the age-related needs are constructed, including modern technological solutions allowing for long-term care for the sick and disabled at their place of living. (Hillcoat-Nalletamby et al., 2010) To this end, various solutions are applied, from those applied at the place of living of the older person to specialist facilities. Services that may be obtained by the elderly at their place of living are care and assistance. This is aimed at supporting these people in their environment to avoid chaos resulting from the change of place of residence. The assistance comprises basic tasks such as shopping, meal preparation or hygiene. Health care services, such as community nurse services, are provided and paid for by the National Health Service (http://england.shelter.org.uk). At their home, an older person may also use funds intended for the adaptation of the dwelling to their changing needs resulting from their current health condition. These services are funded from the Disabled Facilities Grant and allow e.g. to introduce facilities preventing slipping, or facilitate movement of people in wheelchairs.

Another type of housing assistance for the elderly is specialist housing services. These include sheltered housing and retirement villages. In sheltered housing, older people live in independent flats or houses, which allows them to maintain independence, but their dwellings are connected to an alarm system 24/7 which, if needed, alarms the carers that the person requires assistance. In some cases, senior housing provides also for a shared area for integration of the residents. There are also extra care sheltered housing schemes in which care services are more advanced: seniors are assisted in everyday tasks, such as dressing and bathing. The sheltered housing stock is usually allocated by local councils, or sometimes charity or private entities. Since 2006 retirement villages in the UK have been evolving. They are a kind of a community resided by up to 100 households. They are owner-occupied or part-owned. (Hayes, 2006) Dwellings in these estates are designed so as to provide for higher level of support and care than in independent senior dwellings or sheltered housing. The assistance includes services of nutrition, hygiene, or nurse services.

In France, as in the UK, retirement villages are also present (still rarely though). Apart from care services, residents of these villages may use such facilities as a communal swimming pool, lounge, library, exercise and music rooms, and a restaurant. Care services include for example caretaking, cleaning, hairdressing or physiotherapy and others (http://www.afpap.org/). Sheltered apartments are dedicated to households with low income which are able to exist independently to an insignificant extent and require specialist services. Older people have individual dwellings and share such rooms as the dining room or the laundry facility. Sheltered apartments are intended for rent, whereas serviced apartments (résidence avec services pour 
personnes âgées or simply résidence services) operate similarly to sheltered ones but it is usually possible to purchase a dwelling in this stock. In France there are also conventional retirement homes, which may have additional specialist care facilities, however, these are not obligatory.

Table 1: Solutions for senior housing in Sweden, the United Kingdom, France and Poland

\begin{tabular}{|c|c|c|c|c|}
\hline & Sweden & United Kingdom & France & Poland \\
\hline $\begin{array}{l}\text { Types of } \\
\text { senior } \\
\text { housing (with } \\
\text { "ageing in } \\
\text { place" idea) }\end{array}$ & $\begin{array}{l}\text { Living at home } \\
\text { Dwellings for independent } \\
\text { senior living } \\
\text { Assisted living residence } \\
\text { Nursing home } \\
\text { Specialized care }\end{array}$ & $\begin{array}{l}\text { Sheltered or } \\
\text { retirement housing } \\
\text { Assisted living } \\
\text { Retirement villages } \\
\text { Help in seniors } \\
\text { homes: } \\
\text { - care and support } \\
\text { - adaptations }\end{array}$ & $\begin{array}{l}\text { Conventional } \\
\text { retirement homes } \\
\text { Sheltered apartments } \\
\text { Retirement villages }\end{array}$ & \begin{tabular}{ll}
\multicolumn{2}{l}{ Social assistance: } \\
$-\quad$ social service \\
- $\quad$ adult day care \\
- $\quad$ centres \\
- & heltered housing \\
- & communcare sector: \\
- & long-term nursing \\
& care
\end{tabular} \\
\hline Beneficiary & $\begin{array}{l}\text { Over } 55 \text { years, for assisted } \\
\text { living residence even over } 70 \\
\text { years }\end{array}$ & 55 years and older & $\begin{array}{l}\text { Seniors with low } \\
\text { income }\end{array}$ & $\begin{array}{l}\text { Mostly } 60 \text { years and } \\
\text { older }\end{array}$ \\
\hline Financing & $\begin{array}{l}\text { Municipal taxes } \\
\text { Government grants }\end{array}$ & $\begin{array}{l}\text { Disabled Facilities } \\
\text { Grant } \\
\text { Local authority social } \\
\text { services departments } \\
\text { Charities and private } \\
\text { support organizations }\end{array}$ & $\begin{array}{l}\text { Government agency } \\
\text { - grants and small } \\
\text { grants }\end{array}$ & $\begin{array}{l}\text { The National Economy } \\
\text { Bank } \\
\text { Municipalities } \\
\text { Housing associations } \\
\text { (TBS) }\end{array}$ \\
\hline Regulations & $\begin{array}{l}\text { Swedish Social Services Act } \\
\text { Social Assistance Act of } 12 \\
\text { March } 2004\end{array}$ & $\begin{array}{l}\text { Opportunity Age: } \\
\text { Meeting the } \\
\text { challenges of ageing } \\
\text { in the } 21^{\text {st }} \text { century } \\
\text { Building a society for } \\
\text { all ages } \\
\text { Lifetime Homes, } \\
\text { Lifetime } \\
\text { Neighbourhoods: A } \\
\text { National Strategy for } \\
\text { Housing in an Ageing } \\
\text { Society } \\
\text { Policy paper } 2010 \text { to } \\
\text { 2015 government } \\
\text { policy: older people } \\
\text { Future of ageing }\end{array}$ & $\begin{array}{l}\text { Plan solidarité grand } \\
\text { âge 2007-2012 } \\
\text { Plan National } \\
\text { 'Bien Vieillir' 2007- } \\
2009 \\
\text { Seniors et Cité }\end{array}$ & $\begin{array}{l}\text { Government scheme } \\
\text { "Senior +" }\end{array}$ \\
\hline
\end{tabular}

Source: Own study based on national documents and literature review (Edstrom and Gustafsson (2011), Gruis and Priemus (2008), Fukushima et al. (2010), Hillcoat-Nalletamby et al. (2010), Holmqvist et.al (2014), Wisniowska-Szurlej et al. (2017), National Housing Programme).

Senior housing in the compared countries takes diverse forms. In Sweden, France and the UK emphasis is placed on the huge influence of such decisions on the quality of life of the elderly. In Poland, there are not many solutions that would emphasize that much the idea of ageing in place. To a large extent this results from limited funding for such projects. In western countries a vital role is played by government subsidies and municipal taxes, whereas in Poland there are limited forms of funding for these types of residential housing. Furthermore, the main care service provider in Poland for older people is the family, while the aim in western countries is to transfer that burden to specialist institutions operating within municipalities or as charity organizations. In these countries the idea of ageing in place is embedded into the senior housing development strategies, whereas in Poland the government scheme "Senior+" provides for care at day care centres, and the funds from the national budget are intended mainly for adapting adult day care facilities. Moreover, people who created model dwellings for the elderly in Poland according to the idea under analysis emphasized these were not activities supported by the government but only a grass-roots initiative. 


\section{Conclusion}

The analysis of the solutions implemented to secure the housing needs of the elderly in Poland as compared to France, the UK and Sweden shows a discrepancy between Poland and the selected EU countries in terms of arrangement and availability of dwellings for older people. Due to the population ageing process and decreased care provision potential within families, it is essential to allow the elderly to maintain their independence within their place of living and to provide for their comfort and quality of life. As compared to France, the UK and Sweden, Poland lacks a complex, long-term housing policy aimed at securing the needs of older people. The current legal regulations and investment projects implemented in Poland are not of systemic nature, but are often an attempt to implement partial solutions developed in countries with a longer and richer tradition of social housing. Due to the expected increase of the number of older people within the population, the demand for senior-friendly dwellings, both in Poland and in the other countries under analysis, will grow. It will be possible to face up the challenges in the field of housing sector development only based on the adoption of a coherent model which has to be developed based on the analysis of the stock available locally and the implementation potential.

\section{References}

Bowling, A. et al. (2003). Let's ask them: A national survey of definitions of quality of life and its enhancement among people aged 65 and over. International Journal of Aging and Human Development, 56(4), 269-306.

Clapham, D. \& Kintrea, K. (1984). Allocation systems and housing choice. Urban Studies, 21, 261-269.

Czischke, D. (2012). Conceptualizing social enterprise in housing organizations. Housing Studies, 27, 418-437.

Donner, Ch. (2000). Housing policies in the European Union. Theory and Practice, Austrian Federal Ministry of Economic Affairs and Labour, Vienna, Austria.

Edstrom, A. \& Gustafsson, M. (2011). Elderly living in Sweden. Present solutions and future trends. KTH Architecture and the Built Environment, [Online]. Available: http://www.diva-portal.org/smash/get/diva2: 491657/FULLTEXT01.pdf.

Esping-Andersen, G. (2001). What will the welfare state be like in the 21st century? Similarities and differences in the countries of Europe. ESPRIT, 2, 122-150.

Eurostat (2015). Past and future population ageing trends in the EU. Statistics Explained. [Online]. Available: http://ec.europa.eu/eurostat/statistics-explained/.

Eurostat (2016a). [Online]. Available: http://ec.europa.eu/eurostat/statisticsexplained/index.php/Population_ statistics_at_regional_level/pl.

Eurostat (2016b). [Online]. Available: http://ec.europa.eu/eurostat/data/database?node_code=proj.

Eurostat (2017). Population structure and ageing. [Online]. Available: http://ec.europa.eu/eurostat/statisticsexplained/index.php/Population_structure_and_ageing.

Fukushima, N. et al. (2010). The long-term care system for the elderly in Sweden. ENEPRI Research Report No. 89. [Online]. Available: http://www.ancien-longtermcare.eu/sites/default/files/ENEPRI\%20_ANCIEN _\%20RR\%20No\%2089\%20Sweden.pdf.

Giada Meda, S. (2014). No country for old men? Italian families facing the challenges of an aging society. Journal of Comparative Family Studies, 65(2), 275-292.

Gonyea, J.G. \& Burnes, K. (2013). Aging well at home: Evaluation of a neighborhood-based pilot project to "put connection back into community". Journal of Housing for the Elderly, 27(4), 333-347.

Gruis, V. \& Priemus, H. (2008). European competition policy and national housing policies: International implications of the dutch case. Housing Studies, 23, 485-505.

GUS (2013). Wyniki narodowego spisu powszechnego ludności i mieszkań 2011. Podstawowe informacje o sytuacji demograficzno-społecznej ludności Polski oraz zasobach mieszkaniowych.

Hayes, P. (2006). Housing support for older people: A good practice guide. [Online]. Available: https://docuri.com/download/housing-and-support-for-older-people-good-practice-guide_59c1d1eff581710b 2864c088_pdf.

Hillcoat-Nalletamby, S. et al. (2010). Ageing populations and housing needs: Comparing strategic policy discourses in France and England. Social Policy \& Administration, 44(7), 808-826. 
Hoagland, G.W. (2016-17). The economic, fiscal, and financial implications of an aging society. Journal of the American Society on Aging, 40(4), 6-22.

Holmqvist, E. \& Magnusson, T.L. (2014). Swedish welfare state and housing markets: Under economic and political pressure. Housing and the Built Environment, 29, 237-254.

Houben, P. P. J. (2001). Changing housing for elderly people and co-ordination issues in Europe. Housing Studies, 16(5), pp. 651-67.

Iwanski, R. (2016). Opieka dtugotermiowa nad osobami starszymi. Cedewu, Warszawa.

Iwanski R. (2013). Subtainable development of furar areas and social position of the elderly. Folia Pomeranae Universitatis Technologiate Stetinensis. Oeconomica, 299(70), 81-90.

Kemeny, J. (1992). Housing and social theory. London, United Kingdom: Routledge.

Kemeny J. (1955). From public housing to the social market: Rental policy strategies

in comparative perspective. London, United Kingdom: Routledge.

Klevmarken, A. \& Lindgren B. (2008). An ageing economy in an international perspective. Simulating an Ageing Population: A Microsimulation Approach Applied to Sweden, 285, 1-29.

Komisja Europejska (2010). Raport second biennial report on social services of general interest. Commission Staff Working Document, Bruksela.

Lennartz, C., Haffner, M. \& Oxley, M. (2012). Competition between social and market renting: a theoretical application of the structure-conduct-performace paradigm. Journal of Housing and the Built Environment, 27, 453-471.

Lunenfeld, B. \& Stratton, P. (2013). The clinical consequences of an ageing world and preventive strategies, Best Practice \& Research Clinical Obstetrics \& Gynaecology, 27(5), 643-659.

Malpass, P. (2008). Housing and the new welfare state: Wobbly pillar or cornerstone? Housing Studies, 23, 1-19.

Manley, D. \& Van Ham, M. (2011). Choice-based letting, ethnicity and segregation in England, Urban Studies, 48(14), 3125-3143.

National Housing Programme. [Online]. Available: http://mib.gov.pl/2-NPM.html.

Priemus, H. (1997). Growth and stagnation in social housing: What is 'social' in the social rented sector? Housing Studies, 12(4), 549-560.

Rataj, Z. \& Suszynska, K. (2017). Znaczenie społecznego budownictwa mieszkaniowego w zrównoważonym rozwoju. Progress in Economic Sciences, 4. [Online]. Available: http://pes.pwsz.pila.pl/index .php/PES/article/view/114.

Schnure, C. \& Venkatesh, S. (2015). Demographic and financial determinants of housing choice in retirement and the rise of senior living. [Online]. Available: http://dx.doi.org/10.2139/ssrn.2588026.

Strączkowski, Ł. \& Suszynska, K. (2013). Senior customers' attitudes on the housing market (in the light of research conducted on the local market in Poznań). ITCRES, Bratysława.

Suszynska, K. and Boruta, M. (2017). Comprehensive housing solutions for seniors - A response to demographic challenges of the future. Świat Nieruchomości, 2, 45-50.

Vandenbroucke, G. (2016). Aging and wealth inequality in a neoclassical growth model. Federal Reserve Bank of St. Louis Review, 98(1), 61-80.

Van Daalen G. \& Van Der Land M. (2008), Next Steps in Choice-based Letting in the Dutch Social Housing Sector. European Journal of Housing Policy, 8(3), 317-328.

Vanleerberghe, P. et al. (2017). The quality of life of older people aging in place: a literature review. Quality of Life Research, 26(11), 2899-2907.

Wim, J.A. \& Van Den Heuvel (2015). Value reorientation and intergenerational conflicts in ageing societies. Journal of Medicine and Philosophy, 40(2), 201-220.

Wisniowska-Szurlej, A. et al. (2017). The influence of 3 months of physical exercises and verbal stimulation on functional efficiency and use of free time in an older population under institutional care: Study protocol for a randomized controlled trial. Trials, 19, 1-11.

Wei, L. et al. (2015). Study on the quality of the senior housing based on Maslow's hierarchy of needs. International Conference on Measuring Technology and Mechatronics Automation, Nanchang, China, 10841086.

WHO Centre for Health Development (2004). A glossary of terms for community health care and services for older persons. Geneva: World Health Organisation.

World Bank Data (2017). [Online]. Available: http://databank.worldbank.org/data/reports.aspx ?source=health-nutrition-and-population-statistics\#.

World Bank Data (2017). [Online]. Available: http://databank.worldbank.org/data/reports .aspx?source=health-nutrition-and-population-statistics\# [access: 19.10.2017] 